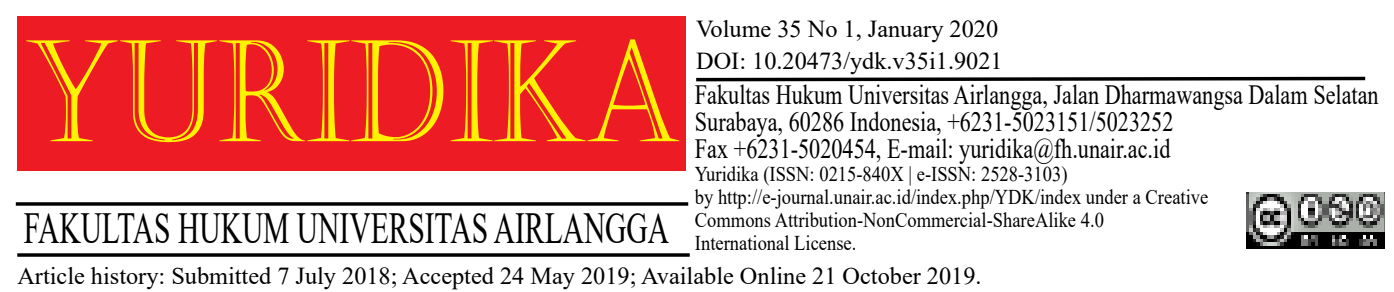

\title{
Application of Al-Ijarah Al-Maushufah Fi Al-Dzimmah for Infrastructure Project Financing in Indonesia
}

\author{
Rega Felix and Lastuti Abubakar \\ regafelix90@gmail.com \\ Universitas Padjadjaran
}

\begin{abstract}
Islamic bank has a huge potential to involve in large project financing such as infrastructure. The demand for infrastructure provision in Indonesia is growing rapidly, so the Islamic bank should become one of the financial institutions for a financing infrastructure project. One of the products of Islamic bank is lease based contract or ijarah. In 2016, the Indonesian Islamic Scholars Council (MUI) enacted Fatwa that allowed ijarah contract for a forward obligation or called alijarah al-maushufah fi al-dzimmah (IMFD). IMFD has some characteristics that equitable for infrastructure project needs, such as for long term financing. The main issues in this research are to drawn a model for infrastructure project financing by applying IMFD and observe the readiness of Indonesian regulation to support the implementation of IMFD on infrastructure project financing. The type of research is the normative study, and the approach of this research having four methods approach among others are statute approach, conceptual approach, cases approach, and comparative approach. The results of this research are model for infrastructure project financing by applying IMFD is by combining musharakah-istishna'ijarah (IMFD) and regulation in Indonesia is not ready enough to support the implementation of IMFD on infrastructure project financing because combination of three contracts like musharakah-istishna'-IMFD, implementation of liquidated damages in istishna' contract, and allowance IMFD in infrastructure project are not regulated in Indonesia.
\end{abstract}

Keywords: Al-ijarah Al-aushufah Fi Al-dzimmah (IMFD); Islamic Bank; infrastructure.

\section{Introduction}

The purpose of the establishment of the Indonesian state is for the welfare of its people. In the context of efforts to prosper the people, good economic development is needed. One indicator of economic development is infrastructure development. The infrastructure supports the economy since its role can facilitate the production process and distribution flow that can reduce the price of a product so that it can 
be reached by the wider community. Infrastructure also has a function to carry out public services so that people can access their rights to welfare.

Based on the assessment of the Global Competitive Index for the 20162017 period conducted by the World Economic Forum, Indonesia's infrastructure development is ranked 60th out of 138 countries. ${ }^{1}$ Based on data from the Indonesian Central Bureau of Statistics (BPS), Indonesia's Gross Domestic Product (GDP) in the 2017 quarter was IDR. 3,368.8 trillion with economic growth of 5.01\%. ${ }^{2}$ Indonesia noted that investment needs in infrastructure development reached $4.51 \%$ of GDP. Compared to India, which recorded $7 \%$ of GDP to build infrastructure and China, which invests $11 \%$ of GDP, Indonesia is still far behind in terms of infrastructure development. ${ }^{3}$ Based on this matter, then to compete with other countries, Indonesia needs to accelerate infrastructure development maximally.

Based on data of investment needs, there is still a difference in the financing needs of infrastructure development in Indonesia, which amounts to IDR 324 trillion or $17 \%$ of the total needs of IDR 1,924 trillion which cannot be provided by the APBN (State Budget)/APBD (Regional Budget), or capital expenditure by State Ownes Enterprise (SOEs). ${ }^{4}$ There is a gap between infrastructure needs and funds owned by the government so that to cover the gap; government efforts are needed to mobilize private funds to participate in an infrastructure project in Indonesia. Based on these reasons, the solution that can be done by the government is to collaborate between the government and the private party or commonly known as a public private partnership (PPP). Through the PPP scheme, the need for large-scale infrastructure development funds is not fully funded by the government so that the

1 World Economic Forum, 'The Global Competitiveness Report 2016-2017' (World Economic Forum, 2019) <https://www.weforum.org/reports/the-global-competitiveness-report-2016-2017-1> accessed 9 August 2017.

2 Badan Pusat Statistik, 'Pertumbuhan Ekonomi Indonesia Tri Wulan 11-2017' (BPS, 2017) $<$ https://www.bps.go.id/website/images/Pertumbuhan-Ekonomi-Tw-II-2017-ind.jpg > accessed 9 August 2017.

3 Eko Nur Surachman, 'Dana Dukungan Tunai Infrastruktur (Viability Gap Fund): Harapan Baru Pembangunan Infrastruktur Di Indonesia' (Kementrian Keuangan Republik Indonesia, 2018) $<$ https://www.kemenkeu.go.id/sites/default/files/Dana Dukungan Tunai Infrastruktur VGF Harapan baru pembangunan infrastruktur di Indonesia.pdf $>$ accessed 9 August 2017.

4 ibid. 
private party can participate in investing in the infrastructure sector by obtaining certain returns as profits.

Infrastructure projects generally require great funds. Therefore the private party will also find it difficult if it has to fulfill all financing with its capital. Based on this matter, the private party will generally propose financing to financial institutions. The most common source of funding through financial institutions is through banking institutions. In Indonesia, the banking system implemented is a dual banking system, a system that allows customers to choose banks that offer both conventional and Islamic finance products. ${ }^{5}$

The existence of Islamic banking in Indonesia opens an alternative for financing infrastructure projects through sharia-based financing schemes. Indonesia is a country with the largest Muslim population in the world, so the Islamic banking potential is still great. Related to the role of Islamic banking in financing the infrastructure sector, it can now be said that it is still far lesser than the role of conventional banking. The major perpetrator in infrastructure project finance is still mostly carried out by the conventional bank. Therefore Islamic bank, in general, should involve in syndicated financing with the conventional bank to jointly finance infrastructure project. The financing scheme which involving two different banking system is a challenge because, in principle, the products provided by Islamic and conventional banking are different. To overcome this challenge, the contract of al-ijarah al-maushufah fi al-dzimmah (IMFD) is a solution so that Islamic bank products can be adapted to conventional financing schemes.

Briefly al-ijarah al-maushufah fi al-dzimmah (IMFD) is a lease contract, but the object that is leased does not exist at the time of the contract. In IMFD contract, only the quality, quantity, and specifications of the object to be leased are only stipulated in the contract. In Indonesia, IMFD contract has been allowed based on Fatwa DSN-MUI Number 101/DSN-MUI/X/2016 concerning the contract of alijarah al-maushufah fi al-dzimmah (Fatwa DSN-MUI No. 101/DSN-MUI/X/2016).

5 An-An Chandrawulan, Kompilasi Hukum Bisnis Dalam Rangka Purnabakti (Keni Media 2014).[259]. 
From the characteristics of IMFD contract, this contract is suitable to be applied for project finance that requires the construction phase, so that it fits the characteristics of the infrastructure project. The application of IMFD for financing infrastructure project is not yet commonly used in Indonesia, but abroad IMFD contract has been commonly used to finance infrastructure and other large projects.

Some major projects that have successfully applied the financing model using IMFD contract are the Sohar Aluminum Smelter project in Oman with a combination of istishna' and IMFD, Queen Alia International Airport project in Jordan with a combination of istishna' and IMFD, and the Doraleh Container Port project in Djibouti with a combination of musharakah, istishna' and IMFD. These projects involve two different banking system, namely conventional banking and Islamic banking, with their respective portions. These projects are a landmark deal that IMFD contract can be applied to infrastructure project financing along with conventional banking. The successful implementation of IMFD contract for financing infrastructure project abroad has made IMFD contract also potentially be applied in Indonesia in infrastructure project finance. The most important thing to implement this potential is that the financing model that has been successfully implemented must comply to the regulations in Indonesia. Based on the above background, the purpose of this study is to describe the infrastructure project financing model through the application of IMFD and to assess the readiness of regulations in Indonesia related to the implementation of IMFD for financing infrastructure project.

\section{Public-Private Partnership in Infrastructure Project}

Infrastructure is the foundation of a country's economic development. E.R. Yescombe provides an understanding of infrastructure; it is: facilities which are necessary for the functioning of the economy and society. ${ }^{6}$ According to E.R. Yescombe infrastructure based on its functions is divided into two, namely

E.R. Yescombe, Public Private Partnership : Principles of Policy And Finance (Elsevier 
economic infrastructure and social infrastructure. ${ }^{7}$ Economic infrastructure, such as transportation, public utility networks (waterways, electricity, waste), which play an important role in supporting daily economic activities. Social infrastructure, such as schools, hospitals, libraries, and jail, in which it plays an important role in supporting the social life of the community. ${ }^{8}$ This division is similar to the existing division in Presidential Regulation No. 38 of 2015 concerning Government Cooperation with Business Entities in Infrastructure Provision (Presidential Regulation No. 38/2015) which also divides infrastructure into two categories namely economic infrastructure and social infrastructure. ${ }^{9}$

The model of infrastructure development in various countries has developed. Many types of infrastructure procurement models have been born to date. ${ }^{10}$ The involvement of the private sector in infrastructure procurement is often known as a public-private partnership (PPP), which has a wide variety of models. E.R. Yescombe describes where there is a gradual development of the infrastructure procurement model that is increasing the involvement of the private sector: ${ }^{11}$

Figure 1. Infrastructure Procurement Model Based on Public and Private Roles

\begin{tabular}{|c|c|c|c|c|c|c|}
\hline \multirow[b]{3}{*}{ Caetirat Type } & \multirow[t]{2}{*}{ Pellik project } & \multicolumn{5}{|c|}{$\longrightarrow \longrightarrow$ Prines pevitec } \\
\hline & & \multicolumn{5}{|c|}{$\rightleftarrows$ PMlic-Privat Pariandip $\longrightarrow$} \\
\hline & 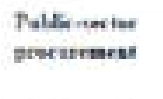 & 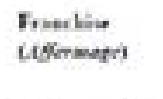 & $\begin{array}{l}\text { Drige- Doial } \\
\text { Flasace } 0 \text { perste } \\
\text { (DBEO) }\end{array}$ & $\begin{array}{l}\text { Aaik-trasifet" } \\
\text { Operste (BTO)": }\end{array}$ & $\begin{array}{l}\text { Neido Oyet wh } \\
\text { Traester (BOT) }\end{array}$ & $\begin{array}{l}\text { Analdowe: } \\
\text { Operate (BOO) }\end{array}$ \\
\hline Caesarecties & Patur werere & Palas andert & Pwate unera & Punaveserax & Alicaseneria & Pressectiat \\
\hline Opretation & Pulke sectese & Prrite seciot & Priale sectot & Arwote sccke & Antwe iccter & Prwme decter \\
\hline Omaetillypti & Potie instice? & Pastis iectar & Poble iecter & 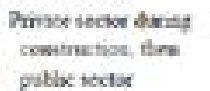 & 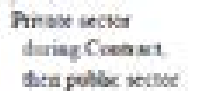 & Prone uter \\
\hline Who pase & PMilie inctiot: & Eim & Pobst secter & Rabie uciet er auen & $\begin{array}{l}\text { Pulbe shctet } \\
\text { or wam }\end{array}$ & 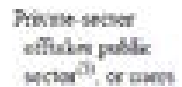 \\
\hline Maen paid? & an: & Prwate secros & Perrate usace & Promare secase & Drisse ucho & Presse ucier \\
\hline
\end{tabular}

Source: Author' Result

\footnotetext{
${ }^{7}$ ibid.

${ }^{8}$ ibid.

9 Article 5 of the Presidential Regulation Number 38 of 2015 concerning Government Cooperation with Business Entities in the Provision of Infrastructure

${ }^{10}$ Dwinanta Utama, 'Prinsip Dan Strategi Penerapan "Public Private Partnership" (2010) 12 Jurnal Sains dan Teknologi Indonesia <http://ejurnal.bppt.go.id/index.php/JSTI/article/view/857>.[147].

11 E.R. Yescombe (n 6).Op. Cit. [12].
} 
Multilateral financial institutions such as the World Bank, Islamic Development Bank, etc. work together to make references on PPP, and provide a definition of PPP, it is "a long term contract between a private party and a government entity, for providing a public asset or service, in which the private party bears significant risk and management responsibility and remuneration is linked to performance". ${ }^{12}$

The PPP model in infrastructure procurement has been adopted by the State of the Republic of Indonesia through Presidential Regulation No. 38/2015. According to the Presidential Regulation, PPP means cooperation between the government and business entities in the provision of infrastructure for public interest by referring to specifications that have been previously set by ministers/heads of institutions/regional heads/state-owned enterprises/regional owned enterprises, which are partially or wholly use business entity resources by taking into account risk-sharing among the parties. The definition given by Presidential Regulation No. 38/2015 has similarities to the definitions given by multilateral financial institutions; thus PPP by Presidential Regulation No. 38/2015 has the same characteristics as PPP in general.

One of the objectives of the establishment of PPPs is to meet the fund needs on an ongoing basis in the provision of infrastructure through the deployment of private funds. ${ }^{13}$ From these objectives, it can be said that Indonesia is currently developing and requires massive infrastructure development to sustain economic growth, but with the availability of limited budgets, therefore the Presidential Regulation was issued to accommodate it. Based on Article 6 of Presidential Regulation No. 38/2015 there is a government entity in the project which is in charge of representing the government in the PPP with the term of the Penanggung Jawab Proyek Kerjasama (PJPK). PJPK can consist of elements of the minister/ or head of institution or head of region or can also be State-Owned Enterprises (SOEs) \& Regional-Owned Enterprises (ROEs). The PPP scheme will be implemented through a PPP agreement between the PJPK as the representative of

12 World Bank, Public Private Partnership : Reference Guide (World Bank 2017).[1].

${ }_{13}$ Article 3 of the Presidential Regulation Number 38 of 2015 concerning Government Cooperation with Business Entities in the Provision of Infrastructure. 
the government and the private sector called the Badan Usaha Pelaksana (BUP) or commonly called project company. ${ }^{14}$ The project company is generally a special purpose legal entity or often known as a special purpose vehicle (SPV). ${ }^{15} \mathrm{SPV}$ is a joint venture company formed by a sponsor company for project execution. The function of making SPV is to limitate the responsibility of the sponsor company or often called to ring-fenced the sponsor companies so that each risk will depend on the SPV Company. ${ }^{16}$

The PPP agreement between the PJPK and BUP is an important thing in the PPP because it contains the rights and obligations of the parties. Therefore the preparation of the PPP agreement must be considered. In general, PPP projects usually involve state assets. Article 33 of the Presidential Regulation No. 38/2015 stipulated that if there is a use of assets held/owned by the government to BUP, then the assets are prohibited from being pledged as collateral. Regarding the use of state asset in PPP, the provisions of Government Regulation Number 27 of 2014 concerning Management of State/Regional Property (Government Regulation No.27/2014) should also apply to PPP. Related to the use of state assets for the provision of infrastructure regulated in Article 38 to Article 41 of the Government Regulation No.27/2014.

Article 39 paragraph (5) of the Government Regulation No.27/2014 stipulated that the project company in infrastructure provision, during the period of cooperation in the provision of infrastructure are prohibited from pledging, mortgaging or transferring state/regional assets that are the object of cooperation in the provision of infrastructure. Article 39 is intended so that in the PPP scheme does not cause the government to lose infrastructure assets that are cooperated to a third party, because the existence of a transfer to a third party will make it difficult for the government to recover the asset.

\footnotetext{
${ }^{14}$ Article 41 of the Presidential Regulation Number 38 of 2015 concerning Government Cooperation with Business Entities in the Provision of Infrastructure.

15 E.R. Yescombe, Principles of Project Finance (Elsevier 2014).[7].

16 ibid.
} 
Another important aspect of PPP is the financing aspect. In the PPP scheme, not all financing comes from the project company's equity financing. In general, the project company will seek financing from financial institutions. By Article 42 of Presidential Regulation No. 38/2015, BUP must have obtained financing for the PPP at the latest 12 months after the PPP agreement was signed. This period of time can be extended by a maximum of 6 if the failure of the financing phase is not caused by the negligence of the BUP. Based on this, BUP must be able to find potential sources of financing to promptly finance the project.

\section{Islamic Banking in Public-Private Partnership}

One alternative source of financing to fill the gap in the lack of funding needs for infrastructure development is through sharia-based financing. The principles of Islamic banking is the banks have an obligation prescribed by law to run its business by Islamic principles which differ from conventional banks. ${ }^{17}$ The Islamic banking sector in Indonesia has experienced huge growth over the past few years. The growth of the Islamic banking industry is reflected in the number of Islamic banking service providers. There are 12 Islamic Commercial Banks operating fully in the Indonesian market with 22 Islamic Business Units at the end of 2015. ${ }^{18}$ The branch network of Islamic Commercial Banks and Islamic Business Units has also grown from 1,737 offices in 2011 to 2,301 in 2015, reaching a CAGR (Compound Annual Growth Rate) of $7.28 \%$ and representing more than $7 \%$ of the total banking branches in Indonesia. ${ }^{19}$ The total assets of Islamic Commercial Banks and Islamic Business Units have also experienced growth from around IDR.145 trillion in 2011 to IDR. Two hundred ninety-six trillion in 2015 so that reached a high CAGR of $19.5 \%$ in the same period. Total deposits and financial assets have also increased from 2011 to 2015 , reaching CAGR of $18.96 \%$ and $20.02 \%{ }^{20}$

\footnotetext{
${ }^{17}$ Ro'fah Setiawati, 'Sharia Governance On Islamic Banking: Spiritual Rights Perspective On Consumer Protection In Indonesia' (2017) 2 Diponegoro Law Review <https://ejournal.undip. ac.id/index.php/dlr/article/view/15336>. [238].

${ }^{18}$ Bappenas, Masterplan Arsitektur Keuangan Syariah Indonesia (Bappenas 2016).[80].

19 ibid.

20 ibid.
} 
The growth of the Islamic banking sector has continued to grow over the past few years, but the total market share of Islamic Commercial Banks and Islamic Business Units has only reached $4.83 \%$ of the total banking sector at the end of $2015 .{ }^{21}$ This market share is considered relatively low when compared to other Islamic countries with a much smaller population and economic levels, such as Malaysia and Saudi Arabia. In each of these countries, the Islamic banking market share reaches $20 \%$ and $53 \%$ of the total domestic banking market. ${ }^{22}$ One aspect that inhibits the growth of an Islamic bank in Indonesia is the lack of variety of its product. ${ }^{23}$

Globally, the growth of Islamic banking assets is mostly contributed from the Middle East region, which is the country of origin of Islam itself. The financing portfolio of Islamic banking in the region is also expanding to be able to finance infrastructure projects. It is undeniable that global Islamic banking assets are still far below conventional banking. However, this situation is not an obstacle for Islamic banks involved in infrastructure project financing because Islamic principles do not prohibit a project being financed by Islamic banks parallel with conventional banks simultaneously.

The infrastructure project financing scheme involving an Islamic bank and the conventional bank is simultaneously referred to as parallel financing. ${ }^{24}$ Based on the results of a World Bank study, even sharia-based financing has conformity with the PPP concept in infrastructure project finance based on: ${ }^{25}$

1. The foundation of Islamic finance is based on the principle of asset-backed financing with a balanced risk distribution by the PPP scheme;

2. Islamic finance can be treated not only in the jurisdiction of Muslim countries;

3. There is no requirement that all infrastructure project financing must be by sharia; Islamic banks can run in conjunction with conventional banks to finance the same project.

\footnotetext{
21 ibid.

22 ibid.

${ }^{23}$ Lastuti Abubakar and Tri Handayani, 'Percepatan Pertumbuhan Perbankan Syariah Melalui Implementasi Tata Kelola Syariah’ (2017) 2 Jurnal Law and Justice $<$ http://journals.ums.ac.id/index. $\mathrm{php} / \mathrm{laj} / \mathrm{article} / \mathrm{view} / 3417>$.[125].

24 World Bank, Mobilizing Islamic Finance For Infrastructure Public Private Partnerhip Report (World Bank 2017).[39].

25 ibid.
} 
In Indonesia, parallel financing for infrastructure projects is not common yet. In practice in Indonesia, several infrastructure projects have been implemented with Islamic finance, but only involve in syndicated financing between Islamic banks only. The infrastructure project that has successfully implemented Islamic finance is the Soreang-Pasirkoja Toll project. For larger projects, the present capital adequacy of an Islamic bank is a barrier for an Islamic bank to finance the project without involving the conventional bank in syndicated financing. Based on this, parallel financing with the conventional bank is a possibility if Islamic bank wants to be involved in large infrastructure project financing. This scheme has been made possible because syndicated financing between Islamic bank and the conventional bank has been allowed by Fatwa DSN-MUI No. 91/DSN-MUI/VI/2012 concerning Syndicated Financing (Fatwa No. 91/DSN-MUI/VI/2012) as long as there is a separation of contract and account documentation.

\section{The Concept of Al-Ijarah Al-Maushufah Fi Al-Dzimmah}

In Indonesia Al-Ijarah Al-Maushufah Fi Al-Dzimmah (IMFD) contract is a new product, which was enacted at the end of 2016 through the Fatwa DSNMUI No. 101/DSN-MUI/X/2016 . According to the Fatwa, IMFD means a lease contract for the usufruct of an item ( (ain) or service ( 'amal) which at the time of the contract only stipulate the characteristics, quantity, and quality (specifications). Classic scholars did not define IMFD, but the contract IMFD been discussed in the chapter about the object that can be leased. ${ }^{26}$ Afterward, IMFD definition was given by contemporary scholars, including Abu Ghuddah, who provides the definition:

"AIMAD (Author: IMFD) is that wherein the mu'ajjir (lessor) adheres to rendering usufruct stipulated thoroughly -by the qualities of salam- enough to eliminate the potential conflict about the usufruct, whether the object of the object is such as leasing a stipulated car, or human services such as tailoring and teaching". ${ }^{27}$

${ }^{26}$ Abu Talib Mohammad Monawer, Al-Ijarah Al-Mawsufah Fi Al-Dhimmah : Theory and Aplication (IBFIM 2017).[15].

${ }^{27} \mathrm{ibid}$. 
Abu Talib Mohammad Monawer gave a brief definition of IMFD, namely: «transferring the ownership stipulated in the liability in exchanger for counter value with a condition». ${ }^{28}$ Related to the IMFD legality, there are differences of opinion by the ulama. Ulama who allow is based on the permissibility of salam based on Surah Al-Baqarah verse 282 which allows transactions for the future obligation (forward). Disagreements exist in classics scholars who, according to Nazih Hammad and Ahmad Nassar, Hanafi scholars did not allow the IMFD because the usufruct must be specific and clear as a condition of the ijarah. ${ }^{29}$ According to Abu Talib Mohamad Monawer, Hanafi did not banned IMFD, contemporary scholars who said Hanafi forbade the IMFD are not conducting extensive research on the Hanafi text. Thus four classical scholars (Hanafi, Maliki, Syafii, and Hambali) allowed IMFD contract. ${ }^{30}$

AAOIFI has also allowed IMFD contract as stated in the sharia standard AAOIFI No. 9 paragraph $3 / 5$ that stipulated :

"An ijarah contract may be executed for assets carried out by the lessor to be delivered to the lessee according to accurate specifications, even if the assets are described as not owned by the lessor. The case is that the asset is available during the duration of the contract, giving the lessor the opportunity to acquire or to produce it. It is not a requirement for lease that the rental should be as long as the lease is not executed according to the contract of Salam (salaf). Should the lessee receive an asset that does not conform to the description, then he is entitled to reject it and demand an asset that conforms to the description". ${ }^{31}$

The majority of scholars allow the IMFD contract, but in its application, there are still differences of opinion between the ulama, such as the issue of $u j \mathrm{rah} / \mathrm{rent}$ payments in advance. The legal basis governing IMFD is the same as salam. Therefore some Shafìi scholars such as Shams Al-Din Al-Ramli stated that ujrah must be paid in advance, while Ibn Qayyim stated that ujrah might be paid in installments with arguments even though the basis of his legality is salam, but ijarah is

\footnotetext{
28 ibid. [16].

29 ibid.[28].

30 ibid.[33].

31 See article 3 paragraph 5 of the 2010 Shariah Standard For Islamic Financial Institution issued by the Accounting and Auditing Organization for Islamic Financial Institutions (AAOIFI).
} 
essentially different from salam. ${ }^{32}$

In its application, if IMFD has to be paid in advance, it faces difficulties to be applied in practice, because in general the IMFD contract is used as a sub-contract of other contracts such as in the musharakah mutanaqisah (MMQ). Based on this, Fatwa DSN-MUI takes a lightening view, so that ujrah can be paid in advance or installments.

Another important rule in IMFD is the existence of Hamish jiddiyah, namely ujrah, which is paid before usufruct are received by the lessee. Hamish jiddiyah can be recognized as a profit by the Islamic bank. When the usufruct has been received by the customer, Hamish Jiddiyah will automatically become the ujrah for the usufruct received by the customer. ${ }^{33}$

\section{Application of Al-Ijarah Al-Maushufah Fi Al-Dzimmah for Infrastructure Project Financing}

The application of IMFD in financing large projects has only begun to be applied since the 2000s. Before the 2000s, ijarah already used for project finance such as in Equate Petrochemical Project in Kuwait in $1996 .{ }^{34}$ Another project that already used ijarah for project finance was Maconda and Truman Park Project in USA which used istishna'- ijarah. ${ }^{35}$ In that era, the application of ijarah contract was used for usufruct that already exists, which is differ from IMFD that the usufruct is not already yet. One of the projects that began applied IMFD for project finance was the Sohar Aluminum Smelter project in Oman. Financing on the Sohar Aluminum Smelter project involves two different banking systems. A tranche of Islamic finance of US \$260 million is arranged by ABN AMRO Bank, Citibank, Emirates Bank, Calyon, Gulf International Bank, WestLB, Royal Bank

\footnotetext{
${ }^{32}$ Abu Talib Mohammad Monawer (n 26). Op. Cit., [47].

${ }^{33}$ Fatwa DSN-MUI No. 101/DSN-MUI/X/2016 about Al-Ijarah Al-Maushufah Fi Al-Dzimmah.

${ }^{34}$ Benjamin C Esty, 'The Equate Project : An Introduction To Islamic Project Finance' (2000) 5 Journal of Project Finance $<$ https://jsf.iijournals.com/content/5/4/7>. [7-8].

${ }^{35}$ Michael J.T. McMillen, 'Islamic Shari'ah Compliant Project Finance : Collateral Security and Financing Structure Case Studies' (2001) 24 Fordham International Law Journal <https://www. researchgate.net/publication/239606246_Islamic_Shari'ah-_Compliant_Project_Finance_Collateral_Security_and_Financing_Structure_Case_Studies/citations $>$.[1237].
} 
of Scotland, Abu Dhabi Commercial Bank, BNP Paribas, Société Générale and Standard Chartered Bank. ${ }^{36}$

The sharia financing scheme used for Sohar Aluminum Smelter project was a combination of istishna'-ijarah (IMFD). ${ }^{37}$ Through the istishna «- IMFD scheme, the underlying asset will be transferred to the Islamic banks. Thus, Islamic banks legally carry the risk of these assets, but Islamic banks are not competent in the management of these assets. If there is a harmful incident to the third party for the operation of the asset, then Islamic banks are responsible for the loss to the third party. Given the limitations of Islamic banks responsibilities and to anticipate these risks, SPV companies are formed that represent for and on behalf of Islamic banks. ${ }^{38}$ SPV Companies will hold the title of the assets so that the liability for the project assets is limited. Creditors in the Sohar Aluminum Smelter project are not only Islamic banks, therefore SPV Islamic banks will also become security agents for the benefit of all creditors for both Islamic banks and conventional banks.

Another important thing in the scheme of Sohar Aluminum Smelter project financing is liquidated damages/penalties clause in istishna' contract. ${ }^{39}$ Liquidated damages function, so that project companies are serious in carrying out the construction phase. IMFD contract is very dependent on the construction phase because, in reality, ijarah is applicable when the usufruct of the asset is received by the lessee. For this reason, liquidated damages functions to ensure the seriousness of the contractor so that the IMFD contract can effectively be implemented. The nominal in liquidated damages is equitable to the rate of ujrah in the IMFD contract so that when there is a delay or failure of construction will reduce the risk of loss for Islamic banks. ${ }^{40}$

${ }^{36}$ Islamic Finance News, 'Sohar Aluminium Smelter Project Islamic Finance Facility, in : Deals of The Year Handbook 2006' (Islamic Finance News, 2006) < https://www.islamicfinancenews. com/sohar-aluminium-smelter-project-islamic-finance-facility.html $>$ accessed 20 October 2017.

${ }^{37}$ Alan J. Alexander, 'Shifting Title and Risk: Islamic Project Finance with Western Partners' (2011) 32 Michigan Journal of International Law <https://repository.law.umich.edu/mjil/vol32/ iss $3 / 5 />$.[605].

${ }^{38}$ Islamic Finance News (n 37).Loc. Cit.

39 ibid.[37].

40 ibid. 
The successful application of IMFD for financing large projects such as the Sohar Aluminum Smelter project makes other Islamic banks want to apply it in an infrastructure project. Afterward, the application of IMFD for infrastructure projects with the PPP scheme was successfully implemented in the Queen Alia International Airport (QAIA) project in Jordan. ${ }^{41}$ The sharia financing scheme applied in this project is the istishna)- ijarah (IMFD) scheme. ${ }^{42}$ The difference with the Sohar Aluminum Smelter project is that only one Islamic bank participant in this project is the Islamic Development Bank (IsDB) and the conventional bank participant is International Finance Corporation (IFC). ${ }^{43}$ In this project, IsDB did not form an SPV company that acted on behalf of IsDB. With no SPV company being made, the asset title will be held by IsDB, which in this project, IsDB is one of the creditors and will be the holder of the project asset title.

The unfair condition occurs when the title of the asset is held by IsDB, while the conventional bank does not hold the title of the asset, because when a default occurs by the project company, IsDB can sell its assets without the approval of another creditor to repay the debtor obligation precede to another creditor. On the other hand, if IsDB acted as a guarantor for conventional bank debt portion, then conventional bank have a preferential position for the security over the asset. To overcome this, a security trustee agreement was formed. ${ }^{44}$ Through a security trustee agreement the title of the project assets held by IsDB as legal owner, but for those assets, the conventional bank also becomes a beneficial owner for security over the asset. If the project company is the default, IsDB can directly sell the assets, and because IsDB was also bound to the security trustee agreement, the proceeds of the sale must be shared pari pass $u$ with a conventional bank. ${ }^{45}$

\footnotetext{
${ }^{41}$ World Bank (n 24).Op.Cit. [50].

42 ibid.

${ }^{43}$ Edward Farquharson, How To Engage With The Private Sector in Public Private Partnership in Emerging Markets (World Bank 2011).[100-101].

44 Madhavi Gosavi, 'Norton Rose Presentation: Queen Alia International Airport Project Jordan' (Ministry of Finance, 2009) <http://www.mofep.gov.gh/sites/default/files/docs/pid/pfa_ ppp_presentation_2009_15.pdf $>$ accessed 12 December 2016.

45 ibid.
} 
The Sohar Aluminum Smelter and QAIA Projects are examples of the successful application of IMFD by transferring underlying assets from project companies to Islamic banks (both directly through SPV and banks). In some countries, infrastructure asset on PPP is prohibited from being transferred by the project company to third parties. Indonesia is a country that prohibits the transfer of infrastructure asset to third parties in a PPP scheme. Therefore the istishna'IMFD will be difficult to implement if it must require the transfer of underlying assets. Academics and Practitioners together sought a solution to overcome this problem so that a scheme to apply IMFD was found which without the need to make a complete transfer of the project asset with a combination of musharakah.

The application was carried out on the Doraleh Container Port project in Djibouti. Financing in this project is very complex because it involves a variety of contracts for the tranche of Islamic banks as well as involving conventional banks. The contract was used in this project is a combination of musharakah -istishnar-ijarah (IMFD). ${ }^{46}$ With the complexity of the financing schemes, this project has become a landmark deal which is currently often become reference in the application of IMFD for infrastructure projects through PPP.

The application of the musharakah is for joint ownership of the project assets between Islamic banks and project company. There are advantages in implementing musharaka in infrastructure projects, one of which is to overcome the problem of prohibiting the transfer of project assets to third parties. Through the musharaka there is no transfer title of the project assets to Islamic banks, but Islamic banks will invest some funds for the project in a joint venture (syirkah). This is possible because based on scholar opinions in syirkah amwaal, the main purpose is not on the transfer of the title of the financed assets, but to make a profit from syirkah.

In the Doraleh Container Port project, musharakah are combined with istishna> and IMFD. In another example, combination of musharakah and

\footnotetext{
${ }^{46}$ Mondher Bellalah, Islamic Banking And Finance (Cambridge Scholar Publishing 2013).[42].
} 
IMFD has generally been applied in house ownership financing through musharakah mutanaqisah (MMQ). In Indonesia, a combination of musharakah with IMFD has been permitted with the enactment of the Fatwa DSN-MUI on IMFD. The purpose of house ownership finance is that the customer owns the house he wants, not for making any profit from the ownership of the house. On the other side, there is no need for a bank to own the house because, in principle, those who want to own our customers. Therefore customers will gradually purchase the shared ownership (hishah) of the house from Islamic banks, so the share proportion for the bank at that house will be diminished. Islamic bank does not need to hold the asset title considering that in syirkah amwaal it is permissible, but in terms of musharakah that requires profit, IMFD went into effect.

In Malaysia, house ownership finance is being built using a combination of musharakah - istishna> - IMFD. Istishna < is used by Islamic bank to customers so that customers bind to build houses that are to be built for Islamic banks. ${ }^{47}$ This is done to reduce the risk to the bank if the house fails to be built by the developer, the bank does not need to sue the developer, but quite to the customer on the failure of construction based on the principles istishna', and with the agreement istishna' customers may incur liquidated damages, so it can cover bank profits equitable to the amount stipulated as ujrah in IMFD. ${ }^{48} \mathrm{Abu}$ Talib Moham ad Al Monawer criticized the application of istishna to customers because the customer is not sani> or an expert for the construction of the house. He said that the bank relinquished the responsibility of providing assets, Islamic banks should have bind istishna 'contracts with the developer who is the real contractor of the house, not to his customer. ${ }^{49}$

The musharakah - istishna' - IMFD scheme in financing house ownership is similar to the financing of the Doraleh Container Port project. Islamic banks make a joint venture as syirkah with project companies, then the project company is obliged

\footnotetext{
${ }^{47}$ Abu Talib Mohammad Monawer (n 26).Op. Cit. [80]

48 ibid.[86].

49 ibid.[86-87].
} 
to construct the project based on istishna for Islamic banks, and at the same time an IMFD agreement was also signed. With IMFD, the project can generate profits which will then be allocated to syirkah to be distributed according to the nisbah agreed between Islamic banks and project company. The Ujrah rate will be equivalent to the conventional bank rate, so that between Islamic banks and conventional banks can go hand in hand. Differ with house financing in Malaysia, In Doraleh Container Port project, who acted as sani' in istishna' was project companies as the main contractor. Thus the application liquidated damages was possible to prevent loss caused by project companies default.

The Sohar Aluminum Smelter Project, Queen Alia International Airport, and Doraleh Container Port are examples of the succeed of IMFD contract in financing large projects. These examples could become a precedent for the application of IMFD in another region. Each project has a different variation of the model as described previously. Each model has obstacles with the readiness of existing regulations in Indonesia. The first model with the scheme of having underlying asset transferred to SPV companies encountered obstacles when the regulation in Indonesia prohibited object of the assets from being transferred to third parties.

Similar to the first model, the second model also requires underlying assets to be transferred to Islamic banks so that it will face the same obstacle. Afterward, in the second model, the Islamic bank will become security trustee for the project assets which the concept of security trustee has not been recognized in land law system in Indonesia, although Indonesian legal system gradually accepts trust from common law system. ${ }^{50}$ To be applied in Indonesia, the two models above require a significant amendment to the legal system in Indonesia. This amendment will take a long time, which in the end, the potential for the application of alijarah al-maushufah $f i$ al-dzimmah to finance infrastructure projects will be hampered. For alternative, Financing model in Doraleh Container Port project

50 Lastuti Abubakar and Tri Handayani, 'Implikasi Kegiatan Usaha Penitipan Dengan Pengelolaan (Trust) Dalam Aktivitas Perbankan Terhadap Pembaharuan Hukum Perdata Di Indonesia' (2014) 15 Jurnal Litigasi <journal.unpas.ac.id/index.php/litigasi/article/view/68>.[114]. 
that applied musharakah - istishna '-ijarah (IMFD) should become one of the precedent model to be applied in Indonesia. In the Doraleh Container Port project, Islamic banks form syirkah with the project company. In syirkah, the project assets ownership will be shared between an Islamic bank and project company in share value. Islamic bank does not need any title of the asset. This concept is a solution when infrastructure assets cannot be transferred from a project company to the third parties. Thus this model does not contravene with Article 33 paragraph (1) of Presidential Regulation No. 38/2015 jo. Article 39 paragraph (5) PP No. 27/2014. In terms of Doraleh Container Port financing model will be applied in Indonesia through PPP, the proposed combination scheme of musharakah-istishna ijarah (IMFD)contracts can be carried out as follows :

Figure 2. Model of Musharakah - Istishna> - IMFD in PPP

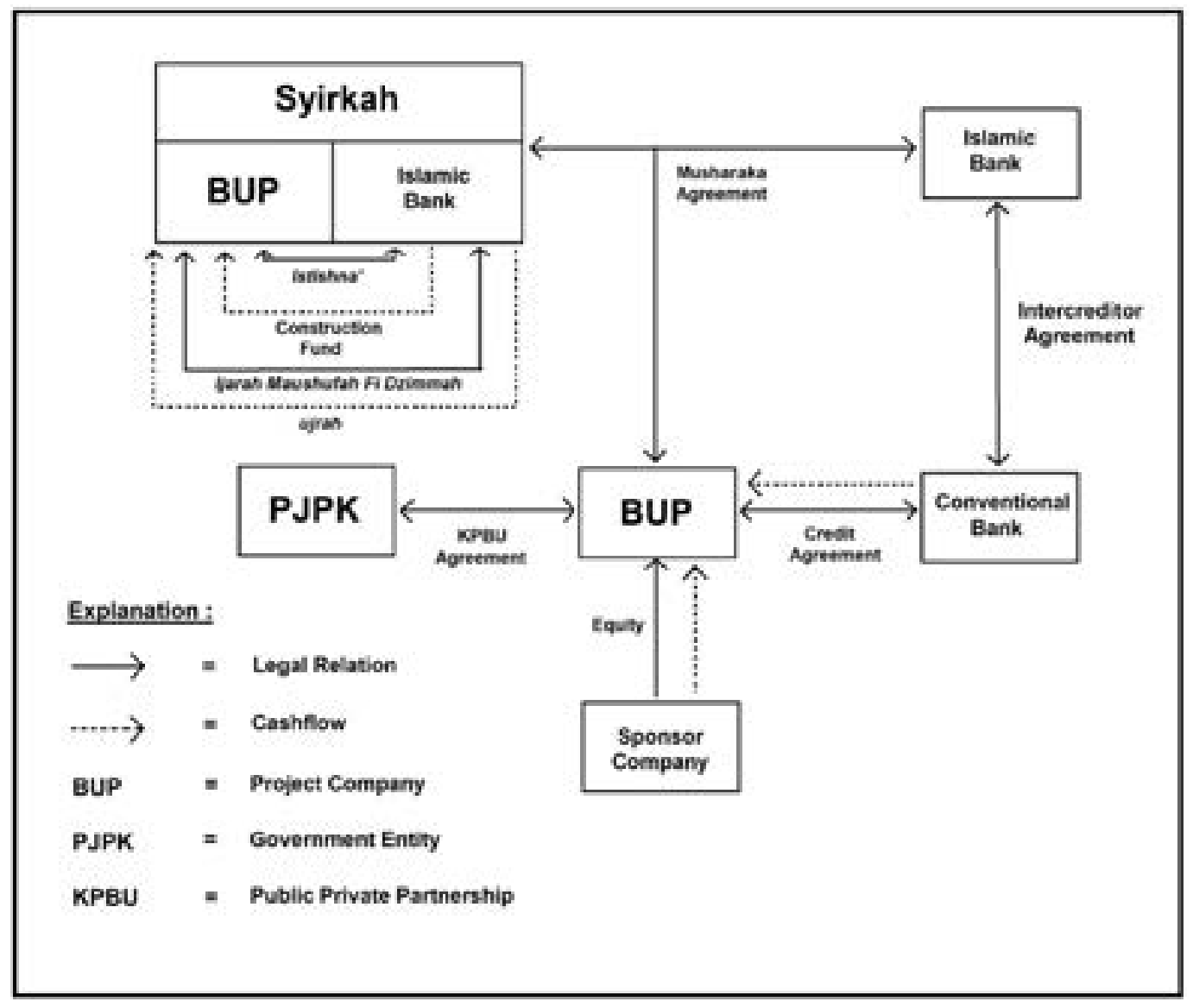

Source: Author' Result 
In the above model, istishna' enact an important role, so that project company is serious in carrying out construction, especially with the binding of liquidated damages clause if the project company is a breach of istishna' contract. The application of liquidated damages is permissible in the istishna contract based on AAOIFI Article 6/7 sharia standard no. 11 and also based on Majma> Fiqh Al-Islami No.66/3/7 dated 9-14 May 1992 with the concept of syarth jaza>i. ${ }^{51}$ Permissibility of syarth jaza' $i$ or liquidated damages is based on principle istishna' contract is not a debt contract (dayn).

FatwaDSN-MUIregulated this in the concept of ta' widh and ta'zhir. Ta s widh is a form of indemnity. According to the Fatwa DSN - MUI No. 43/DSN-MUI/ VIII/2004,ta swidh cannot be set at the beginning of the contract with a certain nominal value. The concept of ta widh in Indonesia categorizes istishna' contracts as a form of debt ( dayn) which differs from practiced abroad for allowing liquidated damages that have been set in istishna' whose nominal equitable to the rate of ujrah. Taszhir, in principle, is a penalty so that customers truly carry out their obligations. It is permissible to stipulate the nominal of ta'zhir in contract, but the amount paid of the ta'zhir will be given to social activities. Based on this, Fatwa DSN - MUI has not accommodated the anticipated risk of loss for bank in istishna' when sani $\ll$ is the project company who due to his late negligence in construction as stipulated in the AAOIFI and majma> fiqh al-Islami .

Combination of three contracts such as in the Doraleh Container Port project has never been regulated in Indonesia. Fatwa DSN-MUI only regulated the combination of musharakah and ijarah, which not including combination with istishna', nevertheless in general IMFD will intersect with the construction phase. Based on this, a combination of musharakah - istishna'-IMFD has not has strong legal-based yet. Thus, If IMFD will be applied for infrastructure project

51 يجوز أن يتضمن عقد الاستصناع شرطاً جزائياً بمقتضى ما اتفق عليه العاقدان ما لم تكن هناك ظروف قاهرة

Free translation: (allowed in the istishna agreement to include syarth jaza'i / liquidated damages / clause penalty if needed, except in the case of force majeur) 
financing in Indonesia, some regulation is needed. Based on Article 26 Law No. 21 Year 2008 concerning Islamic Banking sharia principles for Islamic bank is regulated by Fatwa MUI and afterward enacted in Bank Indonesia Regulation or nowadays is Otoritas Jasa Keuangan (OJK), so MUI and OJK as regulator should enacted regulation to support the application of IMFD for infrastructure project financing in Indonesia.

Based on the regulatory constraints mentioned above, then to implement the proposed infrastructure project financing model through the application of alijarah al-maushufah fi al-dzimmah, regulatory support is needed by issuing:

a. Fatwa DSN-MUI concerning on the allowance of liquidated damages/syarth jaza' $i$ in istishna';

b. Fatwa DSN-MUI concerning on the allowance of a combination of musharakahistishna'-IMFD;

c. OJK Regulation regarding application of IMFD for infrastructure project finance.

\section{Conclusion}

Financing model through the application of al-ijarah al-maushufah fi aldzimmah can be applied with a combination of musharakah-istishna'-ijarah (IMFD) scheme. Through the scheme, the Islamic bank will have shared ownership of assetbased on musharakah contracts, and henceforth the construction duty is carried out by a project company based on the istishna> contract. For the shared ownership of the asset, Islamic bank can lease it to project company with an IMFD contract that the ujrah will become a profit for the syirkah and also Islamic bank. Regulation in Indonesia to implement the infrastructure project finance model with the IMFD contract is currently not ready enough. To realize that financing model, supporting regulations are needed, including Fatwa DSN - MUI concerning on the allowance of liquidated damages/syarth jaza>i in istishna', Fatwa DSN-MUI concerning on the allowance of a combination of musharakah-Istishna'-IMFD, OJK Regulation regarding application of IMFD for infrastructure project finance. 


\section{Bibliography}

Abu Talib Mohammad Monawer, Al-Ijarah Al-Mawsufah Fi Al-Dhimmah : Theory and Aplication (IBFIM 2017).

Alan J. Alexander, 'Shifting Title and Risk: Islamic Project Finance with Western Partners' (2011) 32 Michigan Journal of International Law $<$ https://repository. law.umich.edu/mjil/vol32/iss3/5/>.

An-An Chandrawulan, Kompilasi Hukum Bisnis Dalam Rangka Purnabakti (Keni Media 2014).

Badan Pusat Statistik, 'Pertumbuhan Ekonomi Indonesia Tri Wulan 11-2017' (BPS, 2017) <https://www.bps.go.id/website/images/Pertumbuhan-Ekonomi-TwII-2017-ind.jpg> accessed 9 August 2017.

Bappenas, Masterplan Arsitektur Keuangan Syariah Indonesia (Bappenas 2016).

Benjamin C Esty, 'The Equate Project : An Introduction To Islamic Project Finance' (2000) 5 Journal of Project Finance $<$ https://jsf.iijournals.com/content/5/4/7>.

Dwinanta Utama, "Prinsip Dan Strategi Penerapan "Public Private Partnership" (2010) 12 Jurnal Sains dan Teknologi Indonesia <http://ejurnal.bppt.go.id/ index.php/JSTI/article/view/857>.

E.R. Yescombe, Public Private Partnership : Principles of Policy And Finance (Elsevier 2007).

— , Principles of Project Finance (Elsevier 2014).

Edward Farquharson, How To Engage With The Private Sector in Public Private Partnership in Emerging Markets (World Bank 2011).

Eko Nur Surachman, 'Dana Dukungan Tunai Infrastruktur (Viability Gap Fund): Harapan Baru Pembangunan Infrastruktur Di Indonesia' (Kementrian Keuangan Republik Indonesia, 2018) <https://www.kemenkeu.go.id/ sites/default/files/Dana Dukungan Tunai Infrastruktur VGF Harapan baru pembangunan infrastruktur di Indonesia.pdf $>$ accessed 9 August 2017.

Fatwa of DSN -MUI Number 101/DSN-MUI/X/2016 concerning Al-Ijarah AlMaushufah Fi Al-Dzimmah.

Fatwa of DSN-MUI Number 91/DSN-MUI/IV/2014 concerning Syndicated Financing. 
Fatwa of DSN-MUI No. 73/DSN-MUI/XI/2008 concerning Mutanaqisah Musyarakah.

Fatwa of DSN-MUI No. 43/DSN-MUI/VIII/2004 concerning compensation (ta'widh).

Government Regulation Number 27 of 2014 concerning Management of State / Regional Property.

Islamic Finance News, 'Sohar Aluminium Smelter Project Islamic Finance Facility, in : Deals of The Year Handbook 2006' (Islamic Finance News, 2006) <https:// www.islamicfinancenews.com/sohar-aluminium-smelter-project-islamicfinance-facility.html $>$ accessed 20 October 2017.

Lastuti Abubakar and Tri Handayani, 'Implikasi Kegiatan Usaha Penitipan Dengan Pengelolaan (Trust) Dalam Aktivitas Perbankan Terhadap Pembaharuan Hukum Perdata Di Indonesia' (2014) 15 Jurnal Litigasi <journal.unpas.ac.id/ index.php/litigasi/article/view/68>.

_- 'Percepatan Pertumbuhan Perbankan Syariah Melalui Implementasi Tata Kelola Syariah' (2017) 2 Jurnal Law and Justice <http://journals.ums.ac.id/ index.php/laj/article/view/3417>.

Madhavi Gosavi, 'Norton Rose Presentation: Queen Alia International Airport Project Jordan' (Ministry of Finance, 2009) <http://www.mofep.gov.gh/ sites/default/files/docs/pid/pfa_ppp_presentation_2009_15.pdf $>$ accessed 12 December 2016.

Michael J.T. McMillen, 'Islamic Shari'ah Compliant Project Finance : Collateral Security andFinancing Structure Case Studies'(2001)24Fordham International Law Journal $<$ https://www.researchgate.net/publication/239606246_Islamic Shari'ah-_Compliant_Project_Finance_Collateral_Security_and_Financing_ Structure_Case_Studies/citations $>$.

Mondher Bellalah, Islamic Banking And Finance (Cambridge Scholar Publishing 2013).

Presidential Regulation Number 38 of 2015 concerning Government Cooperation with Business Entities in the Provision of Infrastructure.

Ro'fah Setiawati, 'Sharia Governance On Islamic Banking: Spiritual Rights Perspective On Consumer Protection In Indonesia' (2017) 2 Diponegoro Law Review < https://ejournal.undip.ac.id/index.php/dlr/article/view/15336>.

World Bank, Mobilizing Islamic Finance For Infrastructure Public Private 
Partnerhip Report (World Bank 2017).

—_, Public Private Partnership : Reference Guide (World Bank 2017).

World Economic Forum, 'The Global Competitiveness Report 2016-2017' (World Economic Forum, 2019) <https://www.weforum.org/reports/the-globalcompetitiveness-report-2016-2017-1> accessed 9 August 2017.

HOW TO CITE: Rega Felix and Lastuti Abubakar, 'Application of Al-Ijarah Al-Maushufah Fi Al-Dzimmah for Infrastructure Project Financing in Indonesia' (2020) 35 Yuridika. 
--This page is intentionally left blank-- 